Omelyanenko V.

\title{
NATIONAL STRATEGIC INNOVATION SECURITY CONCEPTUALIZATION
}

Об’єктом дослідження є стратегічна інноващійна безпека країни. Необхідність аналізу інноваційного виміру стратегічної безпеки обумовлена тим, що звуження начіональної безпеки до військово-політичного аспекту в прив'язиі до національних інтересів у сфері безпеки та оборони є помилковим підходом в сучасних умовах. Інноваційна безпека є тим компонентом, що пов'язує напрямки досліджень в інтересах забезпечення як військової безпеки країни, так і ї соціально-економічного розвитку.

В дослідженні було використано як класичні наукові методи (аналізу та синтезу, логічного узагальнення, аналогій, порівняльного співставлення), так і спещифічні методи економіки високих технологій та інноваційного менеджменту.

Розроблено концептуальні основи інформащійно-аналітичного забезпечення стратегічної інноваційної безпеки, що передбачають необхідність вироблення обгрунтованих та ефективних управлінських рішень, що інтегрують різні джерела інформащї та спираються на широкий спектр кількісних та якісних методів з фокусом на довгострокову перспективу. На основі аналізу ряду іноземних конщепцій SSM та аналітики національної безпеки визначено спектр завдань, що має вирішуватися в рамках аналітики стратегічної інноваційної безпеки.

Визначено набір індикаторів для визначення оцінки стану стратегічної інновачійної безпеки. Запропоновано розглядати макроіндикатори стратегічної інноваційної безпеки, що:

- відображають відповідність нащіональної стратегї глобальним інноваційним трендам;

- організаційно-управлінські індикатори, що відображають відповідність інноваційної інфраструктури та рівня інноваційних комунікацій в рамках інноваційної системи та з глобальною інноваційною системою вимогам нових інновачійно-технологічних трендів;

- секторальні індикатори інноващійної безпеки, що відображають рівень відповідності галузевих технологій та продуктів перспективним вимогам та специфічним галузевим технологічним траєкторіям.

Завдяки розгляду стратегічної інноваційної безпеки як провідного фактору національної безпеки забезпечується можливість розробки відповідних критеріїв оцінки на основі урахування технологічної динаміки.

Ключові слова: стратегічна інноваційна безпека, начіональна безпека, технологічне прогнозування, технологічна динаміка, державна політика.

\section{Introduction}

Innovation development in modern states is seen as a way of accelerating and transforming development, and also as a way of ensuring systemic competitiveness of the economy. Also, it is the innovation system that allows to occupy a certain niche in the system of the international division of labor and weight in the international arena.

Given the constant technological changes, the state innovation and industrial policy is constantly changing. In developed countries, priority is the development of fundamental and applied science, public-private partnership in the technology sectors and the creation of conditions for the integration of science, education and industry. System studies are also actively conducted to solve strategic tasks of state and public security and sustainable development of the country through innovation projects, including at the international level.

In this context, it is necessary to constantly and systematically identify and monitor existing security risk factors, develop and implement effective and adequate measures to eliminate them. And also the task is determination of the methodological foundations for ensuring national security based on innovation in a strategic perspective.

\section{The object of research and its technological audit}

The object of research is the strategic innovation security of the country.

The need to analyze the innovation dimension of strategic security is due to the fact that narrowing national security in the military and political aspect in relation to national security and defense interests is an erroneous approach in modern conditions. Innovation security is the component linking research directions in the interests of ensuring both the military security of the country and its social and economic development.

The experience of developed countries shows that the innovation component is the main driver of not only economic growth, but also economic well-being in general. On the other hand, the technological dependence of many developing countries, from developed countries, is a serious threat to national security, which in turn subsequently translates into a number of economic and social problems.

Prospectivity of the problems is also emphasized by the findings of the study [1] conducted in the example of transnational corporations (TNCs) based on the theory of behavioral decisions and randomized longitudinal study. It focuses attention on the tendency to reduce the bud- 
gets of strategic development and security, and increased attention will be paid to decisions taking into account the current economic situation or political conjuncture. Thus, both in the public sector and in the business sector, there is every reason to believe that initiatives to ensure strategic security often become secondary.

Therefore, the elimination of strategic threats is possible with the availability of information and analytical support, which will allow monitoring development indicators in time to make decisions that increase the sustainability and ability to develop an effective strategy.

The importance of innovations for national security can be illustrated through technological dynamics and a system-evolutionary approach. Based on this, it is possible to note the need for constant adaptation of the economic system to new technologies. In the absence of adaptation, the national economy may face a number of problems.

In the study [2], a new techno-economic paradigm (technological structure) leads to significant social and economic transformations, which in turn can lead to technological shocks. These transformations can be characterized by the following groups of interrelated technological innovations that are accompanied by other groups of innovations in various spheres (from changing organizational management structures to labor relations):

- new directions of innovations and new forms of organization of production;

- changing the profile of work skills and the corresponding distribution of income in the economy;

- new product assortments with increasing share of technological products;

- change of investment policy at the national and international level in accordance with the way new innovation factors change comparative advantages;

- new wave of entrepreneurship and small business development, based on new technologies and markets; - tendency of large firms to concentrate on new factors and new business models (networks);

- new models of consumption of products (services)

and new models of consumer behavior.

Therefore, the importance of the methodological foundations of strategic innovation security can be viewed from the point of view of the country's development strategy, which is adaptively respected by innovation-based transformation. By classical definition, strategy is a generalized model of the future state of the economy and a set of planned actions to achieve it. From the point of view of changes, the strategy establishes the main directions, objectives and priorities of the activity, determines the critical resources and necessary innovations, including means for implementing priorities and indicators for achieving the planned results.

\section{The aim and objectives of research}

The aim of research is development of the conceptual foundations of strategic innovation security as the basis for building a methodology for managing innovation development in the context of global innovation transformations, in particular, the transition to new organizational forms of the innovation process.

To achieve the aim of research, the following tasks are identified:

1. To conduct a comprehensive analysis of the role of innovation in ensuring national security and identify threats that arises in the context of global technological change.

2. To define the content of strategic innovation security.

3. To develop the main components of information and analytical support for the management of strategic innovation security.

4. To define a set of indicators for assessing the state of strategic innovation security.

\section{Research of existing solutions of the problem}

The field of national strategic security throughout the existence of mankind and states has undergone many modifications: from the traditional militaristic approach and its corresponding factors [3] to the market and raw materials aspect within the framework of economic security [4].

The first signs of the philosophical concept of security are given in the study [5], the author of which notes that at different periods of time creating the state as a form of its organization, the society primarily aimed to ensure its security.

In the study [6], based on the historical approach, the evolution of strategic security of concepts and paradigms is considered. The authors also emphasize that the military aspect was leading up to the end of the World War II, which became a catalyst for the conceptualization and development of a new tool for strategic security research. Since this so-called «golden period» of strategic research, namely, the 1950s and 1960s, this narrowed approach has lost importance, as research safety issues began to include an increasing array of factors.

Thus, in modern conditions, national strategic security is an integrated concept, including technological and innovation aspects, in fact recognizing the country's place in the global economy. In particular, the study [7] substantiates the role of science, technology and innovation in the context of economic prosperity, political stability and defense capacity. Also, the author of the study systematically examines the interrelations between the scientific and technological sphere and the national security system, the lack of a balance between which generates threats for the country.

In the study [5], based on the systematic approach, it is noted that the higher the development degree of the evolutionary system, the more potential dangers and threats arise. This shows that any system of innovation development is interrelated and interconnected with security factors. The modern innovation development model has a significant number of different subsystems, which are characterized by both positive and negative influences.

It is noted in [8] that studies of processes that cause deviations of the economic system from stable trends are one of the most difficult tasks of economic science. The lack of knowledge about such processes leads to unexpected crisis phenomena in production, financial and social spheres. The most important factor of such processes in the post-industrial era is innovation, in particular, NBIC-technologies and technologies of the Industry 4.0 that change the business processes and the logic of innovation management.

Let's believe that the methodology for studying strategic security issues is available for studying various aspects of security and their interrelationships with the purpose of 
predicting and determining cause-effect relationships and interconnections (insecurity systemic drivers).

In studies [9, 10], the importance of the selective component in the implementation of innovation strategies is substantiated that can be realized both within the framework of resource support [11], and through international innovation strategies [12].

For practical purposes, let's suggest to consider the main provisions of the Strategic Security Management (SSM) concept, related to the establishment of effective security programs, including implementation, management and assessment of programs [13]. It should be noted that now in Ukraine at the SSM macro-level is practically not considered by both scientists and practitioners, within the framework of approaches used in developed countries.

In particular, according to a study [14], «strategic security is overwhelmingly based on the nodal government approach, where states are just a node among others. In the transnational context, states still hold a strong position in transnational cooperation. On the contrary, intersectoral cooperation is purely open-ended and not tied to the old cooperative alliances. ... this contains a different combination of actors, which creates more innovation structure beyond the state-center approach». According to this definition, one can see the complexity of the problems of strategic security and the need for its decomposition into separate elements in order to improve the efficiency of the analysis of factors and decision-making.

In this context, the authors of the study [15] emphasize that «because of the changing international strategic security environment, the nations are interested in their security and defense, as a consequence of the complex interaction and interdependence of the phenomenon and of social, economic, military, demographic and ecological processes in the world». In the framework of this research, let's determine that the innovation aspect is characterized by the interconnection of internally external and public-private aspects that creates difficulties for SSM implementation in the innovation sphere, including through institutional and technological design as a methodology for innovation development [16]

A necessary to consider the strategic concept of innovation security is based on technological dynamics [17, 18] and the corresponding evolution of the organizational and economic forms of its implementation.

The study [19] gives an example of cyber threats that are relevant to the United States. In modern conditions, they are extremely serious through the colossal dependence of society and economy on IT innovations and the need to use them even in those processes that can be implemented without a computer or communication interface. According to the authors of this study, this aspect is especially complicated due to the rapid expansion of the Internet of things (IoT) within Industry 4.0, changes the traditional paradigm of business processes and creates a new spectrum of both security and innovation (technological risk) threats at different levels.

Thus, before the countries in modern conditions, the task is determination of the specific features of the influence of the innovation process on national security in a strategic perspective. Further threats and opportunities should be found in the foundations of integrated strategies for innovation development.

\section{Methods of research}

To solve the problems, the research used both classical scientific methods (analysis and synthesis, logical generalization, analogies, comparative comparison, graphoanalytical methods), and specific methods of high technology economics and innovation management.

In particular, the following methods are used to determine strategic innovation security:

- adapted decision-making methods based on optimization of performance indicators;

- system-evolutionary approach and methodology of comparative analytics for studying the role of innovations in different periods in the context of groups of countries;

- methods of technological analysis for determining technological dynamics and technological trajectory;

- methods based on the analysis of schemes for the strategic development of innovation systems and intersectoral high-tech complexes;

- methods of searching for innovation ways of development and methods of integrated economic analysis of development policy.

\section{Research results}

Let's propose to consider the strategic security of the state as a systemic, multilevel and holistic phenomenon that manifests itself as a stable protection of the entire range of national interests (current and future) from various threats (internal and external). At the same time, this security is characterized in the most important spheres for a long period. In other words, the strategic security of the state (country) should be understood as a state in which its strategic interests are protected.

Experts from the Henley-Putnam School of Strategic Security within the National American University study the following aspects of strategic security within the framework of the curriculum: «organize effectively a wide range of strategic security resources and personnel, across multiple agencies and industries, to produce timely, objective, and accurate intelligence and other security-related products. ... ability to effectively communicate and influence top-level decision makers from an interdisciplinary perspective» [20].

In the above approach, it is possible to determine the principal differences in the policy of strategic security, namely:

- intersectoral aspect of strategic security;

- need to understand its goals at higher levels of government;

- attracting a wide range of resources and creating special so-called security products (security-related products), which may include innovation projects and programs.

The identified aspects fully correspond to modern innovation trends, as determined in previous studies [12, 18].

Based on the conceptual foundations of strategic security considered in the research [21] within the framework of the scientific and academic approach, let's suggest to consider innovation security on the basis of the «global threat spectrum» approach.

According to strategic innovation security, it is possible to define both the level and dynamics of innovation development, which ensures protection of national interests from threats in the long term. 
Let's propose to consider the context of strategic innovation security on the basis of the ideas of the following theorists of economic science, innovation and strategic management:

1. Schumpeter's ideas on competition based on innovation and their analysis as the main factor of economic development. Within this approach, innovations are both the basis of competition and the factor shaping the structure of the industry markets. According to this research, it is possible to consider innovations as a factor in the dynamics of the markets of the national economy, which depending on the effectiveness of coordination management, forms opportunities or threats.

2. Hayek concept, in which the competitive market is interpreted as a special information environment that identifies, uses and coordinates the use of knowledge of many independent participants. Accordingly, the role of innovation communications in the economy increases, allowing to realize competitive development.

3. Freeman concept of the national innovation system. According to this concept, the national innovation system is a set of institutions, separately and in complex implements the functions of creating and disseminating new technologies, forming the basis for the formation and implementation of government policies that affect the innovation process.

In developed countries, effective mechanisms ensure high market efficiency and low transaction costs. Due to such mechanisms, competition in these countries is based on new knowledge and technologies (search for knowledge on the Hayek concept), which changes the logic of processes in the economy and the innovation system.

Understanding the strategy in a number of strategic planning schools, in particular the school configuration (Mintsberg), which links the following aspects:

- reaction to changes in the external environment (reactive process);

- transition to a new sustainable position - a configuration with a new set of strategies, structures and principles (proactive process).

Thus, the complexity and variety of modern forms of innovation processes in today's dynamic economic require constant search for new management tools. According to the strategic marketing approach, the state should create and develop competitive advantages in strategic areas of national security.

Experts of Organisation for Economic Co-operation and Development (OECD) emphasize that innovation is not limited to investing in research and development, but also includes, for example, design and branding, which are the most lucrative links in modern global value chains. The above experience of OECD also demonstrates the need for various regulatory measures (which are formed for specific countries and specific time periods) to succeed in innovation development (the «policy mix» approach).

Formation of conceptual provisions for assessing the level of strategic innovation security of the country for development of tools for ensuring permanent development in the long term should be based on:

- adapted by the author principles of sustainable development (set forth in [23]);

- principles of the relationship «security - development»:

1. Principle of coherence of development strategy with

all existing strategies (sectoral, territorial, resource).
This principle determines the consistency degree in the step-by-step implementation of the overall innovation strategy of a safe development strategy.

2. Principle of interaction of the safe development strategy with predictable changes in the external environment (technological dynamics). This principle should be based on the compliance of the development strategy of the subsystems with the predicted changes in indicators (national and in international dimensions) to minimize threats and realize the potentials of the external environment

3. Principle of interaction of the state's safe development strategy with its innovation capabilities. This principle determines the potential for formation of innovation development resources and the correspondence of development strategies to other parameters.

4. The principle of the reality of the development strategy determines the strategic opportunities in implementing complex innovation and investment projects in a certain perspective, in the formation of the necessary amount of resources from all sources.

5. The principle of determining an acceptable level of risk (strategic development risk corridor) associated with the implementation of selected development strategies (a set of strategies). Based on this principle, the level of risk is determined for the activity in terms of the possible size of losses and the generation of threats to strategic security.

6. The principle of economic and social effectiveness of the implementation of the development strategy. It finds conformity to the target strategic attitudes, image, level of controllability of the activity of functional institutes.

7. The principle of system solutions. SSM in the innovation sphere includes activities that unite interrelated political, economic and military leadership, as well as diplomacy and other political and legal aspects.

8. Principle of technological interrelations. Breakthrough innovations can not only significantly change the technical and technological basis of the industry, but also markets, the composition and roles of the subjects, as well as the fundamentals of the economy.

9. The principle of national (local) orientation of innovation development. For development, it is necessary to choose such technological areas that will be associated with the existing potential, welfare problems of the population and building a solid foundation for new technologies and areas of development relevant to a particular country (region).

10. The principle of strategic orientation, which includes the inclusion of an innovation component in programs and development strategies. Strategic priorities define long-term development guidelines for innovation entities, as well as benchmarks for financing the sector of basic and applied science and supporting innovation communications. Important in the framework of this principle is the strategic management culture.

In the study [24], strategic culture is defined as the totality of basic, mental ideological factors (attitudes, principles, values, ideals, norms, mythology and ideology, etc.). They are of strategic importance and exist at the level of consciousness of the national-state elite. They are aimed at the effective use of the entire internal potential of the state (nation) to establish its place in the world, to ensure 
national security. Strategic culture is also defined as a set of models and technologies of behavior and decision-making by the elite in the way of realizing these strategic goals.

Therefore, the understanding of innovations as a key factor should be the basis of a strategic culture and it is precisely its absence leads to the processes and solutions of the short-term perspective indicated in the study [1].

In order to implement certain principles of strategic innovation security within the framework of the state governance mechanism, it is necessary to move away from the traditional understanding of innovations in Ukrainian practice exclusively as the promotion of scientific and technological developments or the support of innovation companies. But the innovation strategy provides for a change in the structure of the economy and innovation processes, the choice of priorities and those directions of development that can provide the country with sustainable development and competitiveness in the future. It is only within the framework of this approach that it becomes possible to shift to ensuring national security in all its components on the basis of innovation effects.

For the objectives of research, let's propose to use the definition of technological trajectories as the ways in which innovation develops at the sectoral level. Thus, the emergence of technological trajectories can be explained by the relationship between scientific achievements, economic factors and institutional variables that are the basis for decisions and strategies of innovation management. This approach allows to combine various factors in development of innovation technological systems.

The combination of different technological trajectories forms the technological dynamics that can be considered at various levels (macro-level, global level, etc.).

Among the main threats in the analysis of technological dynamics, it is worth noting the evolution of the technology base for production of mass products, strategic sectors and sectors critical for national security. In this context, let's note the possible technological dependence through the system acquisition of new technologies (equipment) in foreign firms, which is expressed in limiting the demand for the results of the national innovation system. An alternative to this may be the transition to the stage of innovation and technological development, when an active creation of small innovation enterprises and venture funds is being carried out.

In the meantime, in a number of developing countries, there is a lack of unity in selected innovation priorities in order to concentrate resources on really promising directions. This problem is especially promising in the conditions of transition to a new technological structure, which radically transforms the sphere of management of the formation of competitive advantages. In addition, these countries have limited experience in determining these priorities, based on the maximization of the relationship between them through coordination.

It should be noted that the format of the chosen innovation strategy should significantly influence:

- monetary policy;

- project financing mechanisms;

- modernization of state enterprises and private sector enterprises;

- development of intersectoral clusters;

- introduction of innovation products;

- schemes of access to domestic and foreign markets;
- system of licensing and certification of products.

To confirm this, it is possible to summarize the main goals, tasks and directions of the activities of the US and Chinese administrations in the field of foreign and domestic policy. These countries have the goal of achieving technological leadership, including through diplomacy and international relations.

Therefore, let's come to the need to develop sound and effective management decisions that integrate various sources of information, relying a wide range of quantitative and qualitative methods with a focus on the long-term perspective.

Based on the analysis of a number of foreign concepts of SSM and national security analysts it is determined that within the framework of strategic innovation security analysts the following spectrum of problems should be solved:

- development of quantitative and qualitative criteria for research of innovation safety at the theoretical, strategic, operational and tactical levels;

- development of conceptual frameworks, including the main variables of the innovation security environment, in order to prevent threats arising from the global technological dynamics;

- assessment of information and approaches to assessing the criticality (strategic importance) of technologies (enterprises, priorities, research centers) and the resources necessary to attract strategic innovation security;

- assessment of the nature of the effects of technologies related to strategic management mechanisms and are relevant to promoting effective results in the field of innovation security;

- building models that clarify global and regional events and highlight problems that affect the construction of an effective policy of strategic innovation security;

- assessment and analysis of how the leading countries in the field of strategic innovation security consider the themes of strategic challenges;

- analysis of data from analytical centers, intelligence, counterintelligence, cybernetic and financial intelligence and the synthesis of relevant knowledge for decisionmaking in the field of strategic innovation security;

- conducting fundamental research in the fields of knowledge used in the field of strategic innovation security.

Based on this, it is possible to assess the strategic innovation orientation of development policy through indicators, which should be considered from the point of view of sufficient dynamics of one of the following states of the innovation system:

- innovation activity in the country is limited to stimu-

lating only certain technological innovations;

- innovation activity in the country is limited to stimulating exclusively technological innovations within the priority sectors;

- innovation activity in the country is directed to separate socio-economic innovations;

- innovation activity in the country, reforming the national economy;

- innovation activity in the country influences the development of the global economy.

Thus, the level of strategic innovation security grows from the first to the fourth state of the innovation system, since it is in the latter variant that breakthrough innovations are implemented. According it is possible to 
define such groups of indicators of strategic innovation security:

1. Macro-indicators of strategic innovation security, reflecting the alignment of the national strategy (package of strategies) to global innovation trends:

- volume of financing from various sources of innovation in the technological areas of future technological structures;

- number of personnel engaged in research and development in the areas of future technological structures.

2. Organizational and management indicators reflecting the compliance of innovation infrastructure and the level of innovation communications within the innovation system and with the global innovation system to the requirements of new innovation and technological trends.

3. Sectoral indicators of innovation security, reflecting the level of compliance of industry technologies and products with promising requirements and specific industry technological trajectories. Accordingly, such indicators should be analyzed:

- intensity of costs for technological, marketing and organizational innovations by level in the context of types of economic activity;

- proportion of organizations that simultaneously implemented technological and organizational innovations, in the total number of organizations that carried out technological innovation, in terms of types of economic activity.

The results of the analysis of certain indicators in their systemic relationship should be used to develop development programs and innovation strategies. It is proposed to consider innovation strategies as a set of rules and organizational and economic mechanisms that determine the procedure for selecting and implementing various types of innovations in accordance with the social development orientation).

Based on an understanding of what kind of prejudice may be in the decisions, it is proposed to use the institution of strategic initiators. They make decisions, improve their decisions and help them recognize regulatory rules or optimal solutions.

Fig. 1 shows the developed scheme of analytics of strategic innovation security.

The scheme in Fig. 1 is based on strategic technology analysis, control of certain indicators of innovation development and the development of scientific and methodological foundations of strategic management. And also demonstrates that, within the framework of ensuring strategic innovation security, it is possible not only to protect itself from threats, but also to ensure the development of the country. This can be achieved by developing a system of technological forecasting, organizing the development and implementation of innovation projects of national importance; formation of an institutional environment that stimulates innovation.

\section{SWOT analysis of research results}

Strengths. The strength of research is the justification of strategic innovation security as a leading factor in national security, economic and social development. Using the proposed approach will further develop criteria for assessing strategic innovation security, taking into account technological dynamics. Consideration of strategic innovation security in the international context will allow to combine the strategic foundations of its ensuring the concept of competitive development in international markets, and will also allow the implementation of comparative analysis.

Weaknesses. The weak side is that the practical implementation of the methodology of strategic innovation security requires systemic efforts and strategic thinking and planning, it is difficult to implement under domination of approaches and strategies based on obtaining short-term benefits. It is also quite difficult to implement the function of coordinating intersectoral cooperation in the context of differentiation of ownership patterns and international impacts.

Opportunities. Opportunities for further research are the analysis of the experience of foreign countries, in particular the United States, on improving the institutional environment for strategic forecasting, taking into account the realities of the Ukrainian innovation system.

Threats. Threats to the results of conducted research and their practical implementation are a rapid innovation process and the emergence of breakthrough innovations in various technological sectors. This requires proper monitoring and changes in strategic orientations, requires coordination of interests and coordination at various levels of management. Also, for the practical implementation of the SSM policy in the innovation sphere, an appropriate level of strategic culture is needed in government authorities. 


\section{Conclusions}

1. Comprehensive analysis of the role of innovation in national security and identified threats arising in the context of global technological change is conducted. It is shown that the orientation toward innovation provides a change in the structure of the economic sectors, the choice of priorities and those directions of development that can provide the country with sustainable development and competitiveness in the future. It is determined that the key aspects of strategic security (intersectoral aspect, attraction of a wide range of resources, project management approach) fully correspond to modern innovation trends.

2. The content of strategic innovation security is determined on the basis of the ideas of theoreticians of economic science, innovation and strategic management:

- factors of competition based on innovation and their analysis as the main factor of economic development; - competitive market, which is interpreted as a special information environment;

- concept of the national innovation system;

- understanding of strategy as a tool for development and adaptation.

3. Conceptual bases of information and analytical support of strategic innovation security is developed. They require the development of sound and effective management decisions that integrate various sources of information, which rely on a wide range of quantitative and qualitative methods with a focus on the long-term perspective. Based on the analysis of a number of foreign SSM concepts and national security analysts, a range of tasks is identified, which should be addressed within the framework of strategic innovation security analysts.

4. A set of indicators is determined to determine the assessment of the state of strategic innovation security. It is proposed to consider macro-indicators of strategic innovation security, reflecting:

- compliance with national global innovation trends; - organizational and management indicators reflecting the compliance of the innovation infrastructure and the level of innovation communications within the innovation system and with the global innovation system to the requirements of new innovation and technological trends;

- sectoral indicators of innovation security, reflecting the level of compliance of industry technologies and products with promising requirements and specific industry technological trajectories.

\section{Acknowledgements}

The research was publicly funded by Ministry of Education and Science of Ukraine for developing of research project No. 0117 U003855 «Institutional and technological design of innovation networks for Ukraine national security systemic providing».

\section{References}

1. Workman M. Validation of a biases model in strategic security decision making // Information Management \& Computer Security. 2012. Vol. 20, No. 2. P. 52-70. doi: http:// doi.org/10.1108/09685221211235599

2. Freeman C. The Economics of Industrial Innovation. London: Pinter, 1982. 249 p.
3. Sherman W. C. Air warfare. Air University Press. Maxwell Air Force Base, 2002. doi: http://doi.org/10.21236/ada421698

4. Lensey R. A. China's rise regional stabilizer or U.S. adversary? Monterey: Naval Postgraduate School, 2007.

5. Nikolaenko A. I. Innovation safety in the evolutional development of economic system // Bulletin of Donetsk National University. Series C. Economics and Law. 2013. No. 2. P. 110-113.

6. Koliopoulos C. Historical Approaches to Security // Strategic Studies. The International Studies Encyclopedia. Vol. 5 / ed. by Denemark R. A. Oxford: ISA with Wiley-Blackwell, 2010. P. $3321-3338$.

7. Malits'kiy B. A. Nauka, tekhnologii, innovatsii i natsional'naya bezopasnost': teoreticheskie i prikladnye aspekty. Makarov: KZHT «Sofiya», 2014. 58 p.

8. Dementev V. E. Tekhnologicheskaya neodnorodnost' proizvodstva i tsiklichnost' ekonomicheskogo razvitiya // Zhurnal ekonomicheskoi teorii. 2016. No. 3. P. 40-50.

9. Prokopenko O., Omelyanenko V. Priority Selection Within National Innovation Strategy in Global Context // Economics and Business. 2017. Vol. 31, No. 1. P. 5-18. doi: http:// doi.org/10.1515/eb-2017-0014

10. Omelyanenko V. Innovation priorities optimization in the context of national technological security ensuring // Marketing and Management of Innovations. 2016. No. 4. P. 226-234.

11. Omelyanenko V. A., Kudrina O. Y., Volodin D. V. Conceptual principles of development resources security analysis // Marketing and Management of Innovations. 2017. Vol. 2. P. 280-287. doi: http://doi.org/10.21272/mmi.2017.2-26

12. Omelyanenko, V. A. Analysis of Potential of International InterCluster Cooperation in High-Tech Industries // International Journal of Econometrics and Financial Management. 2014. No. 2 (4). P. 141-147.

13. Karim H. V. Strategic Security Management. A Risk Assessment Guide for Decision Makers. CPP, CSC, 2006. 416 p.

14. Munk T. H. Cyber-security in the European Region: Anticipatory Governance and Practices. Manchester: University of Manchester, 2015. 286 p.

15. Mosoiu O., Oana M. Evolutions and tendencies in the common European security strategy in the context of lobalization // AFASES 2009: Scientific research and education in the air force. Brasov: «Henri Coanda» Air Force Academy, 2009. P. 50-59.

16. Omelyanenko V. Analysis of conceptual aspects of institutional and technological design // Technology Audit and Production Reserves. 2017. Vol. 2, No. 5 (40). P. 31-36. doi: http:// doi.org/10.15587/2312-8372.2018.128651

17. Omelyanenko V. Basics of Optimization Strategy for Integrating Space Industry Technology Package Into Global Value Chains // Economics and Business. 2017. Vol. 30, No. 1. P. 113-125. doi: http://doi.org/10.1515/eb-2017-0010

18. Omelyanenko V. A. Basics of general approach for technological systems analysis: proceedings // Advanced Information Systems and Technologies AIST-2016. Sumy, 2016. P. 29-30.

19. Garwin R. L. Strategic Security Challenges for 2017 and Beyond NAS Annual Meeting. 2017. URL: https://fas.org/ $\mathrm{rlg} /$ nas-challenges.pdf

20. Doctorate in Strategic Security. URL: https://henley-putnam. national.edu/programs/doctorate-strategic-security/

21. Greaves S., Clark T. Strategic Security as a New Academic Discipline // Journal of Strategic Security. 2008. Vol. 1, No. 1. P. 7-20. doi: http://doi.org/10.5038/1944-0472.1.1.2

22. Obnovlennaia Innovacionnaia strategiia OESR: vliianie na nacionalnye strategii stran. 2016. URL: https://oecdcentre.hse.ru/ news/200128013.html

23. Erohin V. Yu. Strategii ustoychivogo razvitiya predpriyatiy: printsipy i kriterii razrabotki // Socialno-ekonomicheskie yavleniia i processy. 2013. No. 3 (49). P. 60-62.

24. Sarkisyan O. L. Koncept «strategichekoy kultury» kak model issledovaniy v oblasti nacionalnoy bezopasnosti: proceedings // Problemy nacionalnoi bezopasnosti v usloviyah globalizacii (mezhdisciplinarnye aspekty). Er.: RAU, 2015. P. 5-14.

Omelyanenko Vitaliy, PhD, Department of Business Economics and Administration, Sumy State Pedagogical University named after A. S. Makarenko, Ukraine, e-mail: omvitaliy@gmail.com, ORCID: http://orcid.org/0000-0003-0713-1444 